\title{
Alternatively spliced exons of the $\beta$ tropomyosin gene exhibit different affinities for F-actin and effects with nonmuscle caldesmon
}

\author{
Mark F. Pittenger ${ }^{1, *}$, Amy Kistler1,† and David M. Helfman ${ }^{1, \neq}$ \\ ${ }^{1}$ Cold Spring Harbor Laboratory, Cold Spring Harbor, NY 11724, USA \\ *Present address: Osiris Therapeutics, Inc., 2001 Aliceanna Street, Baltimore, MD 21231, USA \\ Present address: University of California at San Francisco School of Medicine, San Francisco, CA, USA \\ $\ddagger$ Author for correspondence
}

\section{SUMMARY}

The rat $\beta$-tropomyosin (TM) gene expresses two isoforms via alternative RNA splicing, namely skeletal muscle $\beta$-TM and fibroblast TM-1. The latter is also expressed in smooth muscle where it corresponds to smooth muscle $\beta$-TM. Skeletal muscle $\beta$-TM contains exons 7 and 10, whereas exons 6 and 11 are used in fibroblasts and smooth muscle. In order to study the properties of the alternatively spliced proteins, recombinant TMs derived from bacterial and insect cell expression systems were produced, including the normal $\beta$ gene products, fibroblast TM-1 and $\beta$ skeletal muscle TM, two carboxy-terminal chimeric TMs, TM-6/10 and TM-7/11, as well as a carboxyl-truncated version of each, TM-6Cla and TM-7Cla. The purified TM isoforms were used in actin filament association studies. The apparent $T M$ association constants $\left(K_{\mathrm{a}}\right)$ were taken as the free concentration at half saturation and were found to be $6 \mu M$ for $\beta$ Sk TM, 8.5 for TM-6/10, $25 \mu M$ for TM-1, and $30 \mu \mathrm{M}$ for TM-7/11 at an F-actin concentration of $42 \mu \mathrm{M}$. For the truncated TMs, the values determined were higher still but the binding was not carried out to full saturation. Isoforms were also produced using the baculovirus-insect cell system which produces proteins with an acetylated amino terminus as is normally found in vivo. This modification significantly enhanced the $F$-actin association of TM-1 but not the $\beta$ skeletal TM or the other isoforms. Fibroblast TM-2 or TM-3, both products of the $\alpha$ gene, enhanced the affinity of TM-1 for F-actin, demonstrating different isoforms can act cooperatively on binding to actin. This effect was not detected with the other expressed $\beta$ gene products. The presence of $83 \mathrm{kDa}$ nonmuscle caldesmon was found to enhance the binding of TM-1 for F-actin. This effect was dependent on the presence of both exons 6 and 11, as caldesmon had little effect on the other $\beta$ gene products. Collectively these results demonstrate TMs differ in their affinity for F-actin, which can be altered by other TMs or actin-binding proteins. The $\beta$ tropomyosin isoforms were fluorescently-tagged and microinjected into cultured cells to study their in vivo localization where it was found that each of the full-length TMs bound to microfilaments but, at the light microscopy level, the isoforms were not differentially localized in these fibroblasts.

Key words: $\beta$ tropomyosin gene, F-actin, caldesmon, alternative splicing, tropomyosin

\section{INTRODUCTION}

Most microfilaments have tropomyosin (TM) bound along their length, in the long pitch grooves on either side of the 2start actin filament helix. The assembly and disassembly of microfilaments is a dynamic process repeated many times in a locomoting fibroblast. In addition, once every cell cycle, the complete actin network must be disassembled in readiness for mitosis, and later reassembled. How the association of TMs with actin is regulated is unknown. In the rat, there are known to be sixteen TM proteins expressed from four genes through the use of different promoters and alternative RNA processing. In skeletal muscle, the tropomyosin exists as a heterodimer consisting of one polypeptide from the $\alpha$ gene ( $\alpha$ skeletal muscle TM, 284 amino acids) and one polypeptide from the $\beta$ gene ( $\beta$ skeletal muscle TM ( $\beta$ Sk TM), 284 amino acids). In smooth muscle, the heterodimer is also formed from one polypeptide from the $\alpha$ gene and one polypeptide from the $\beta$ gene, but each is an alternatively spliced product and differs in two exons from the skeletal muscle counterparts. In cardiac tissue, the TM dimer is composed only of $\alpha$ gene product, two chains of the $\alpha$ skeletal TM. There is a wider variety of tropomyosin isoforms in nonmuscle tissues owing to the expression of the four genes, three of which are alternatively spliced. This can result in the expression of as many as eight TM isoforms in a given cell. The cloning of the cDNAs for TMs has led to a better appreciation of the complexity of tropomyosin expression in vertebrates. For example, in rat fibroblasts, the $\alpha$ gene produces TM-2, TM-3, TM-5a and TM$5 \mathrm{~b}$ through the use of two promoters and alternative mRNA processing (Goodwin et al., 1991). These differ in their affinity towards F-actin in the order $5 b>2=3>5 a$, with the 248 amino acid TM-5b capable of displacing the 284 amino acid TM-2 (Pittenger and Helfman, 1992). In this study the F-actin asso- 
ciation appeared to be cooperative for a given isoform but there was not cooperativity between isoforms, with each appearing to compete for F-actin binding sites. The $\alpha$ gene can also produce three brain specific isoforms (Lees-Miller et al., 1990) which are differentially expressed in neuronal cells during development (Stamm et al., 1993) or induced during neurite out growth in PC12 cells (Weinberger et al., 1993). In most smooth muscle and nonmuscle tissues, the $\beta$ gene expresses only one isoform, TM-1. This TM differs from the $\beta$ gene product found in skeletal muscle ( $\beta$ Sk TM) by the inclusion of an alternative internal exon (exon 6 in place of exon 7 ) and an alternative carboxy-terminal exon (exon 11 in place of exon 10, see Fig. 1) (Helfman et al., 1986; Yamawaki-Kataoka and Helfman, 1985). The functional differences between these isoforms are unknown.

While our knowledge of the TM gene family has progressed rapidly in recent years (see Lees-Miller and Helfman, 1991 for review), there is not as yet a clear understanding of the function and regulated expression of nonmuscle TM proteins. The complexity of TM isoform expression is probably not due to functional redundancy, as this complexity has been largely maintained through evolution suggesting important functions that have been conserved through selective pressures. What roles the different isoforms of TM fulfill in evolutionarily diverse organisms is unclear. TM's function in striated muscle contraction has been well studied and tropomyosin facilitates the calcium-sensitive contraction of muscle fibers either by a steric blocking mechanism (Ebashi et al., 1969) or through allosteric interactions (Greene and Eisenberg, 1980). In smooth muscle, our understanding is less complete, but the phosphorylation of associated proteins, notably caldesmon and the myosin light chains, is involved in regulating actin and myosin association (Marston and Smith, 1985). A greater challenge still is to unravel the roles nonmuscle TMs play in different tissue types, given the variety of dynamic actin based structures present in cells. What properties the alternatively spliced exons confer on the TM isoforms is beginning to be elucidated (reviewed by Pittenger et al., 1994) but in order to better understand the characteristics of individual TMs, purified isoforms are necessary. The purification of nonmuscle TM isoforms from endogenous sources has proven difficult owing to their very similar physical and chemical properties. However, several investigators have taken advantage of the availability of cDNA clones for TMs and bacterial expression systems to generate quantities of individual isoforms for biochemical (Bartegi et al., 1990; Cho et al., 1990; Montiero et al., 1994; Novy et al., 1993a,b; Pittenger and Helfman, 1992; Urbancikova and Hitchcock-DeGregori, 1994; this paper) and cellular studies (Pittenger and Helfman, 1992; Prasad et al., 1993; this paper). The results have shown that many of the TM isoforms produced in bacteria can readily bind to F-actin in vitro (Cho et al., 1990; Heald and Hitchcock-DeGregori, 1988; Novy et al., 1993a,b; Pittenger and Helfman, 1992) but that certain TMs require an intact amino terminus or some form of amino terminal extension (Cho et al., 1990; Heald and HitchcockDeGregori, 1988; Montiero et al., 1994; Urbancikova and Hitchcock-DeGregori, 1994). When the isoforms that readily bind to actin filaments in vitro were introduced into cultured cells by microinjection, all were able to compete with the endogenous isoforms and incorporate into the microfilaments and in all cases, appeared to have no detrimental effects on cells (Pittenger and Helfman, 1992; Ranucci et al., 1993; this paper). As yet, the isoforms that have been introduced into cells have not shown differential localization as has been reported using an isoform-specific antibody (Lin et al., 1988).

In this paper, we report the characterization of recombinant TMs derived from the $\beta$ gene using bacterial and insect cell expression systems. F-actin association of TM-1 (which contains the alternatively utilized exons 6 and 11) is shown to be affected by the presence of an acetylated amino terminus, the presence of TM-2, or the $83 \mathrm{kDa}$ nonmuscle caldesmon. The $\beta$ Sk TM (which contains the exons 7 and 10 in place of exons 6 and 11, respectively) showed little such effects. For those isoforms which bound well to actin in vitro, microfilament staining was easily visualized. However, no preferential localization to particular regions of the cell was seen with the labeled proteins. Our previous results also showed that the $\alpha$ gene products TM-2, TM-3, TM-5a and TM-5b showed indistinguishable microfilament staining when fluorescently labeled isoforms were introduced into fibroblasts by microinjection (Pittenger and Helfman, 1992). Taken together, the results suggest that most TMs do not achieve their function through differential localization within the cell. However, the organization of particular TM isoforms along actin filaments is probably not random and may be modified by the presence of other TMs or other actin binding proteins. A discussion of the organization of TMs on microfilaments and a possible model is presented.

\section{MATERIALS AND METHODS}

\section{cDNA expression constructs}

The cDNA clones for rat fibroblast TM-1 and $\beta$ Sk TM have been described (Helfman et al., 1986; Yamawaki-Kataoka and Helfman, 1985). Molecular biology techniques were carried out as described (Sambrook et al., 1989). The bacterial expression plasmid pET8C (Studier et al., 1990) DNA was digested with NcoI and BamHI and the larger vector fragment gel purified. The TM-1 coding sequence was removed from SP64 vector by complete digestion with BamHI and partial digestion with $\mathrm{NcoI}$ and the correct fragment isolated by gel purification. The $\beta$ Sk TM coding sequences present in clone SK22 (Helfman et al., 1986) were removed from pUC9 vector sequences by $\mathrm{NcoI}$ (single site) and BamHI digestion followed by gel purification. These TM coding sequences were then ligated into the NcoI/BamHI cleaved pET8C. Bacterial expression vectors to produce chimeric protein hybrids TM-7/11 and TM-6/10 were constructed by swapping the sequences $3^{\prime}$ of the ClaI site to the SalI site between plasmids SP65 TM-1 and SP65 $\beta$ Sk TM (this was done by Dr Susan Erster, for other purposes in this laboratory). Subsequently, the 3' SalI site was converted to a BamHI site by digestion with SalI followed by nucleotide fill-in with the large fragment of Escherichia coli DNA polymerase I (Klenow fragment) and addition of BamHI linkers. The plasmids were then exhaustively digested with BamHI. The TM-7/11 construct was cut with $\mathrm{NcoI}$ and the proper fragment isolated. The TM-6/10 construct contained two NcoI sites so a partial digest was performed and the correct fragment isolated. These fragments were ligated overnight to the $N c o \mathrm{I} / \mathrm{Bam} \mathrm{HI}$ digested pET8C. Competent $E$. coli was transformed with a portion of the ligation reaction, grown overnight, and colonies checked for appropriate inserts and then selected clones sequenced by the dideoxy-chain termination method (Sanger et al., 1977). Correct DNA constructs were tested for the production of TM proteins upon transformation of BL 21 (DE3) bacteria as described (Pittenger and Helfman, 1992). To produce truncated versions of TM-1 and $\beta$ Sk TM lacking the alternative 
carboxy terminal exons 10 or 11 , the selected bacterial expression construct was digested with ClaI, which cleaves in the conserved exon 9 at codon 254, and BamHI. The large fragment was isolated after gel electrophoresis, the ends filled by use of Klenow fragment, and the plasmid religated. This results in a vector that produces a truncated tropomyosin of 257 amino acids with the last four amino acids being coded by vector sequences before a termination codon is encountered.

For the production of acetylated TMs from SF9 cells, the TM inserts were removed from the pET8C vectors as $X b a \mathrm{I}$ (upstream of the $N c o I$ site and downstream of the bacteriophage $\phi 10$ promoter) to BamHI fragments and inserted at the $\mathrm{XbaI} /$ BamHI position downstream of the polyhedrin promoter of the baculovirus vector $\mathrm{pVL}$ 1392 (PharMingen, San Diego, CA). The linearized virus DNA containing a lethal deletion (BaculoGold, from PharMingen) was cotransfected with the pVL 1392-TM constructs into SF9 cells (American Type Culture Collection, Bethesda, MD). Recombinant viable virus particles in the cell media were passed to new cultures every fourth day and after three rounds of infection the cells were tested for production of TM proteins by polyacrylamide gel electrophoresis.

The rat $83 \mathrm{kDa}$ nonmuscle caldesmon was expressed in host bacteria BL21 (DE3) pLys-S using a full length cDNA clone in pET$11 \mathrm{~d}$ vector (Novagen, Madison, WI) and purified as described (Yamashiro-Matsumura et al., 1988). This particular construct contained a myc epitope tag (EQKLISEEDL) at the amino terminus, away from the actin- and tropomyosin-binding regions of the $\mathrm{C}$ terminus that was useful to follow the purification of the protein.

\section{Purification of expressed proteins from baculovirus and bacteria}

The TMs expressed in bacteria were purified as previously described (Pittenger and Helfman, 1992). The TMs from the baculovirus expression system were purified by similar methods. Briefly, ten 150 $\mathrm{cm}$ plates of SF9 cells (70\% confluent) were infected with $4 \mathrm{ml}$ each of virus stock (approximately $10^{5} \mathrm{pfu} / \mathrm{ml}$ ) for 4 hours and $15 \mathrm{ml}$ of additional medium was then added. After three days, the cells were harvested by gentle scraping and the cells pelleted at $100 \mathrm{~g}$ for 15 minutes at $4^{\circ} \mathrm{C}$. The cell pellet was saved and resuspended in 4 volumes of hypotonic buffer (30 mM KCl, $10 \mathrm{mM}$ Hepes, $\mathrm{pH} 6.8,1$ mM EDTA, 1 mM DTT, 1 mM Pefabloc (Boerhinger-Mannheim) and transfered to a Dounce homogenizer. Triton X-100 was added to the homogenizer to a final concentration of $0.5 \%$. After 10 strokes, $2 \mathrm{M}$ $\mathrm{KCl}$ was added to bring the concentration to $200 \mathrm{mM}$. The homogenate was spun at $100,000 \mathrm{~g}$ for 1 hour and the supernatant saved. The supernatant was brought to $600 \mathrm{mM} \mathrm{KCl}$ and the solution heated to $70^{\circ} \mathrm{C}$ for 15 minutes and denatured proteins were pelleted at $30,000 \mathrm{~g}$ for 15 minutes at $4^{\circ} \mathrm{C}$. The TM remaining in the supernatant was precipitated by the addition of potassium acetate $(\mathrm{pH} 4.5)$ to a final concentration of $30 \mathrm{mM}$. After 20 minutes on ice, the precipitate was pelleted at 3,000 $\mathrm{g}$, and the pellet was resuspended in one original volume of buffer $(100 \mathrm{mM} \mathrm{KCl}, 20 \mathrm{mM}$ sodium phosphate, $\mathrm{pH} 7.0,1 \mathrm{mM}$ DTT) and the $\mathrm{pH}$ adjusted to $\mathrm{pH} 7$ by dropwise addition of $2 \mathrm{~N}$ sodium hydroxide. Any material not in solution was pelleted by centrifugation and discarded. The $\mathrm{pH}$ precipitation step was repeated twice more and the final $\mathrm{pH} 4.5$ pellet was resuspended in $30 \mathrm{mM} \mathrm{KCl}, 20 \mathrm{mM}$ sodium phosphate, $\mathrm{pH} \mathrm{7,} 1 \mathrm{mM}$ DTT and this was loaded onto a $5 \mathrm{ml}$ anion exchange column (Mono Q resin, Pharmacia). The column was washed with three column volumes and the TMs were then eluted with a gradient of $30-600 \mathrm{mM} \mathrm{KCl}$ (also containing $20 \mathrm{mM}$ sodium phosphate, $\mathrm{pH} 7.0$, and $1 \mathrm{mM}$ DTT) in 30 column volumes. Fractions were analysed by SDS-PAGE and appropriate fractions pooled and stored on ice or at minus $70^{\circ} \mathrm{C}$ for long term storage. The yield of expressed protein from insect cells varied from 4-15 mg depending on the TM isoform.

The full length nonmuscle caldesmon cDNA from rat was expressed in bacteria using the pET vector. This construct contained the myc epitope at the amino terminus, away from the putative actin and tropomyosin binding regions. Caldesmon expression was induced with $0.4 \mathrm{mM}$ IPTG and cells harvested 2 hours later. Purification was accomplished as described (Yamashiro-Matsumura et al., 1988) following the initial lysis and centrifugation (Pittenger and Helfman, 1992). Myc epitope antibodies (Oncogene Science, Uniondale, NY) were used to follow purification by western blotting procedures as well as Coomassie Blue staining of SDS-PAGE gels. The yield of caldesmon was much less than for tropomyosin, approximately $1 \mathrm{mg}$ per liter of culture. For the experiments described here, the final purification step involved F-actin binding and repurification as described (Pittenger and Helfman, 1992).

\section{Protein sequencing}

NH2-terminal sequencing was carried out at the Protein Core Facility at Cold Spring Harbor Laboratory essentially as described (Matsudaira, 1987). Results for the first eight cycles are shown in Table 1, with the yield in pmol for each cycle. For the bacterially expressed proteins, the amino acid sequences determined were the correct amino and carboxy termini predicted from the known cDNA codons. The same coding sequences were used for expression in SF9 cells. The TMs produced in SF9 cells could not be sequenced from the $\mathrm{N}$ terminus and proved to have blocked amino termini, presumably due to acetylation, which is known to occur in this expression system. The proteins were of the correct size and on 2-D gels, migrated virtually identically to the bacterially produced full length proteins or TMs partially purified from cultured cells (data not shown). The carboxy terminus of the TMs in bacterial expression plasmids were sequenced using an oligo complementary to internal sequences and reading $5^{\prime}$ to the plasmid squences. For several of the proteins, carboxy-terminal sequencing was carried out using the amino acid analysis of those residues released by carboxypeptidase $\mathrm{Y}$ digestion over time (Pittenger and Helfman, 1992) and provided evidence of correct full length TM proteins (data not shown). The recombinant proteins truncated at the $\mathrm{Cla}$ I site were not subjected to protein sequencing but the expression plasmid for TM-7Cla was sequenced and the expressed proteins were of the expected molecular mass on SDS-PAGE gels.

\section{F-actin binding assay}

F-actin binding assays were performed as described (Matsumura and Yamashiro-Matsumura, 1985; Novy et al., 1993a; Pittenger and Helfman, 1992) or in a buffer containing $100 \mathrm{mM} \mathrm{KCl}, 30 \mathrm{mM} \mathrm{NaCl}$, $20 \mathrm{mM}$ sodium phosphate, $\mathrm{pH}$ 7.0, $0.5 \mathrm{mM}$ EGTA and $1 \mathrm{mM}$ DTT. The results in the two buffers were comparable. Routinely, incubations were for one hour at room temperature in a $70 \mu \mathrm{l}$ volume, followed by sedimentation in an Airfuge (Beckman Instruments, Palo Alto, CA) at 28 psi for 30 minutes or a TLA-100 rotor at $65,000 \mathrm{rpm}$ in the tabletop ultracentrifuge (Beckman Instruments). After centrifugation, the supernatant was removed and mixed with an equal volume of $2 \times$ SDS gel sample buffer. The pellet was carefully resuspended in $140 \mu \mathrm{l}$ of $2 \times$ SDS gel sample buffer. Samples $(10 \mu \mathrm{l})$ of supernatants and pellets were loaded on $12 \%$ polyacrylamide gels using the discontinuous buffer system (Laemmli, 1970). Binding assays were quantified using scanning densitometry as previously reported (Matsumura and Yamashiro-Matsumura, 1985; Novy et al., 1993a; Pittenger and Helfman, 1992) using as standards TMs whose concentration were determined by amino acid analysis in the Protein Core Facility at Cold Spring Harbor Laboratory. All binding studies were performed using $42 \mu \mathrm{M}$ actin.

\section{Fluorescent labeling of proteins and microinjection}

Fluorescent labeling of TMs produced in bacteria or SF9 cells was carried out as previously described (Pittenger and Helfman, 1992). Microinjection of cultured cells was performed by published procedures (Diacumakos, 1973; Graessmann et al., 1979) as detailed previously (Pittenger and Helfman, 1992). 


\section{Cell culture methods}

Cultured rat embryo fibroblasts (REF 52) were grown in DME medium (Gibco BRL, Grand Island, NY) containing 10\% rhehatuin fetal calf serum (Intergen, Purchase, NY), 4,500 mg/l glucose, $50 \mathrm{mg} / \mathrm{l}$ streptomycin, $50 \mathrm{U} / \mathrm{ml}$ penicillin $\mathrm{G}$. Cells were grown in a $5 \% \mathrm{CO}_{2}$ atmosphere at $37^{\circ} \mathrm{C}$. SF9 cells were obtained from PharMingen or the American Type Culture Collection (Rockville, MD) and were grown in TMN-FH media (Sigma Chemical Co., St Louis) supplemented with $10 \%$ fetal calf serum and $1 \mathrm{U} / \mathrm{ml}$ gentamycin, at $27^{\circ} \mathrm{C}$ without $\mathrm{CO}_{2}$.

\section{RESULTS}

\section{Production of tropomyosins in bacteria and insect cells}

The bacterially produced TMs included fibroblast TM- 1 and $\beta$ Sk TM, as well as two chimeric TMs, in which the C-terminal domain of each isoform was exchanged. The resulting chimeric isoforms are herein referred to as TM-6/10 and TM-7/11 (Fig. 1). It is worth noting that these two chimeric TMs have been found to be expressed at low levels from the mouse $\beta$-TM gene (Wang and Rubenstein, 1992). In addition to the full-length TMs, two C-terminal truncated proteins were produced and are referred to as TM-6Cla and TM-7Cla (Fig. 1). The recombinant TMs were expressed constitutively in bacteria as soluble proteins but production levels could be increased approximately two-fold by the addition of IPTG $(0.4 \mathrm{mM}$ final concentration) to early log phase cultures. Bacteria were harvested by centrifugation and lysed by a combination of enzymatic digestion and detergent solubilization. The proteins were purified as described previously (Pittenger and Helfman, 1992) by modification of published procedures used to purify TM from tissue sources including ammonium sulfate precipitation, $\mathrm{pH}$ precipitation of TMs, heat denaturation of contaminating proteins, and ion exchange chromatography. Purification was assessed by SDS-PAGE (see Fig. 2) and also by western blotting, where appropriate. The yield of purified TMs expressed in bacteria varied depending on the isoform but ranged from 10 to $40 \mathrm{mg}$ per liter of bacterial culture. The fulllength final products used in subsequent experiments were greater than $95 \%$ pure, the contaminants being mostly premature termination products or minor degradation products. Several of the TMs were subjected to N-terminal and Cterminal sequencing to ensure that they were full length and retained the $\mathrm{N}$-terminal methionine. The bacterially produced TMs, TM-1 and $\beta$ Sk TM, as well as the chimeras TM- $6 / 10$ and TM-7/11 were found to have the correct $\mathrm{N}$-terminal sequence (see Table 1). The carboxy termini of TM-1 and

Table 1. Amino-terminal sequence analysis of recombinant proteins

\begin{tabular}{lcccccc}
\hline Cycle & TM-1 & B Sk & TM-7/11 & TM-6/10 & TM-6Cla & TM-7Cla \\
\hline 1 & M 28 & M 16 & M 10 & M 6 & M 110 & M 79 \\
2 & D 10 & D 9 & D 12 & D 6 & D 85 & D 47 \\
3 & A 23 & A 16 & A 12 & A 5 & A 89 & A 62 \\
4 & I 12 & I 8 & I6 & I 4 & I 59 & I 37 \\
5 & K 8 & K 5 & K 10 & K 7 & K 115 & K 68 \\
6 & K 12 & K 5 & K 14 & K 8 & K 141 & K 79 \\
7 & K 12 & K 5 & K 12 & K 7 & K 130 & K 78 \\
8 & M 13 & M 9 & M 9 & M 4 & M nd & M 53 \\
\hline
\end{tabular}

TM7/11 were analysed by the release of amino acids over time with digestion by carboxypeptidase $\mathrm{Y}$ which gave evidence of being full length (data not shown, the amino acid sequence is 278-LLELNNL-284 and therefore somewhat redundant).

TMs were produced in SF9 cells both as suspension cultures and attached to tissue culture plates. The tropomyosins produced using the baculovirus expression system were found to have a blocked amino-terminus as expected, presumably due to acetylation which is known to occur in this expression system. The purified proteins were greater than $95 \%$ pure (see

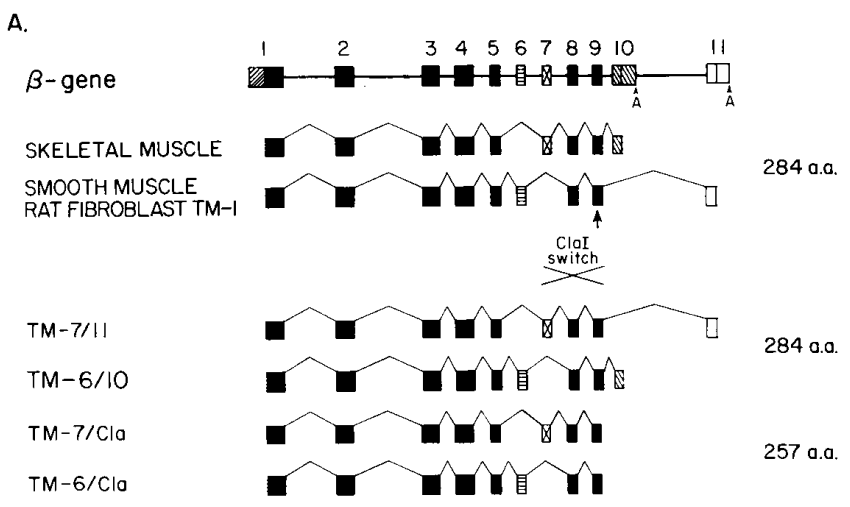

B.

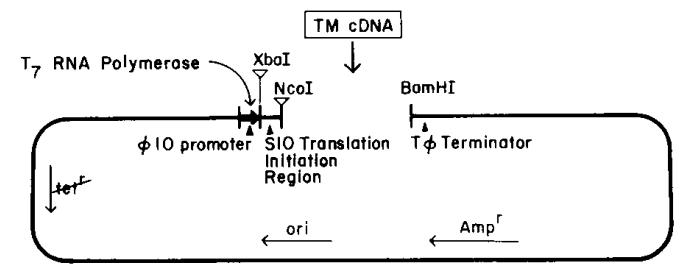

C.

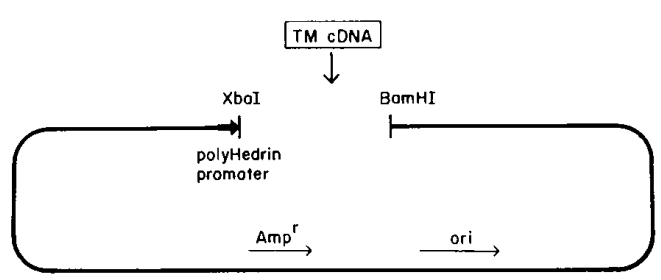

Fig. 1. Diagram of the rat $\beta$ tropomyosin gene products and the expression vectors used in this study. (A) Shown is the exon organization of the $\beta$ gene (using the numbering of exons according to Helfman et al., 1986) and the two alternatively spliced products, skeletal muscle $\beta$ TM and fibroblast TM-1 (identical to smooth muscle $\beta$ TM). The two chimeric proteins TM-7/11 and TM-6/10 were created by exchanging the sequences downstream of the ClaI site, the numbering representing the exons used in each isoform. Two truncated versions were also made by cleavage at the ClaI site (interrupting codon 251), followed by filling the site by use of DNA polymerase (Klenow fragment) and religation. A missense termination signal arises from the vector sequences. (B) The bacterial expression plasmid pET-8c allows the expression of nonfusion proteins when coding sequences are inserted. The TM sequences were subcloned as $\mathrm{NcoI}-$ Bam HI fragments, containing the initiating methionine as part of the $\mathrm{NcoI}$ site, and termination signals occurring just downstream of the coding sequences, prior to the BamHI site. (C) For expression in insect cells, the coding sequences were removed from the pET vector as $X b a \mathrm{I}$ to $B a m H I$ fragments and inserted into the vector pVL1392 (Pharmingen Inc.) downstream of the polyhedrin promoter. 


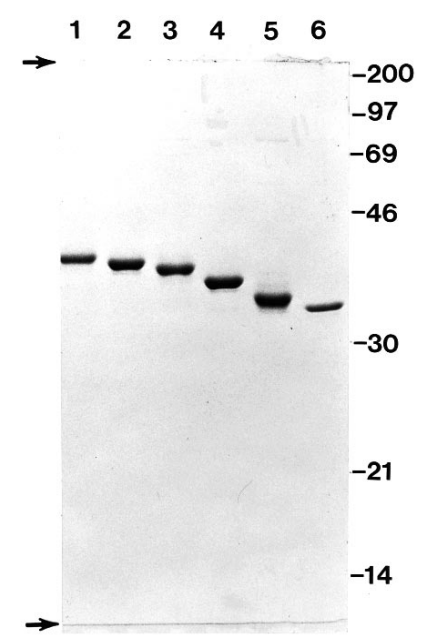

Fig. 2. Purified $\beta$ tropomyosins following expression in bacteria. The tropomyosins were expressed in the bacterial host BL21 containing a DE 3 lysogen with the IPTG inducible T7 polymerase gene and purified as described previously (Pittenger and Helfman, 1992); $3 \mu \mathrm{g}$ of each TM isoform was resolved on a $12 \%$ polyacrylamide gel containing SDS. Lane 1, TM-7/11; lane 2, TM-1; lane 3, $\beta$ Sk TM; lane 4, TM-6/10; lane 5, TM-7Cla; lane 6, TM-6Cla. To the right are shown the positions of molecular mass markers $\left(\times 10^{-3}\right)$. Arrows mark the top and bottom of the gel.

Fig. 4A,B) with minor contaminants being premature termination products or minor degradation products, as they would react with tropomyosin antibodies on blots. Based on the initial wet weight of packed cells, the final yield of purified TMs from the insect cell expression was approximately one third to one tenth of the yield from bacteria, depending on the isoform.

\section{F-actin binding assay with purified tropomyosins}

In order to assess the actin binding affinity of the TM isoforms, F-actin binding assays were performed. Increasing amounts of purified isoforms were incubated with a fixed amount of filamentous rabbit skeletal muscle actin and the F-actin:TM complex was pelleted by centrifugation. The supernatants were removed and the pellets resuspended in an equal volume and aliquots of each were subjected to SDS-PAGE. The resolved proteins were visualized with Coomassie Brilliant Blue dye. The amount of TM bound was quantified by gel scanning and comparison to TM standards whose concentration was previously determined by amino acid analysis. In these experiments, the amount of F-actin pelleted was not affected by the bound TM. Therefore, the individual lanes could be normalized by comparing the actin amounts present. The results show that each of the isoforms binds in a saturable manner (Fig. 3). The association curves are characteristic for each of the isoforms and were performed several times. The apparent TM association constants $\left(K_{\mathrm{a}}\right)$ were taken as the free concentration at half saturation and were found to be $6 \mu \mathrm{M}$ for $\beta \mathrm{Sk}$ TM, 8.5 for TM-6/10, $25 \mu \mathrm{M}$ for TM-1, and $30 \mu \mathrm{M}$ for TM-7/11, at an actin concentration of $42 \mu \mathrm{M}$. For the truncated TMs, the values determined were higher still but the binding was not carried out to full saturation. Bacterially expressed TM-1 bound rather weakly relative to the $\beta \mathrm{Sk}$ TM and the chimeric TM-6/10. TM-7/11 was also found to bind with a low affinity, similar to TM-1. It was noted that proteins whose $\mathrm{C}$ terminus was encoded by exon 10 bound actin with much greater affinity than those containing exon 11 . Whether this was an intrinsic property of the terminal exon or due to improper folding, etc. is not completely clear. However, eliminating the last exons by expressing the truncated TMs resulted in similarly weak binding for each of the truncated forms (see Fig. 3E and F). Several binding assays were also performed in buffers of varying ionic strength (30 to $120 \mathrm{mM} \mathrm{KCl}$ ) with similar results and no change in the relative affinity of the TMs for F-actin (data not shown).

\section{Acetylation of the amino terminus enhances TM-1 binding to filaments}

When tropomyosins isolated from endogenous tissue sources have been sequenced, they have proven to have an acetylated amino terminus as is found for many proteins. Due to the headto-tail overlap which is known to occur for certain TMs bound along the actin filament, this acetylation may be important for proper alignment and cooperative binding. In order to directly ask whether the acetylation of the amino terminus affects the actin affinity of TM-1, we expressed this isoform in an insect cell expression system. The SF9 insect cells are known to carry out protein modifications such as acetylation and limited glycosylation. When expressed in SF9 cells, TM-1 and other isoforms were unable to be sequenced from the amino terminus, presumably due to acetylation. Using this TM-1 in the F-actin binding (Fig. 5a,b) assay, a distinct increase in the binding was evident, with a decrease in the apparent association constant from $25 \mu \mathrm{M}$ to $10 \mu \mathrm{M}$. When the TM $\alpha$ gene product TM-2 was produced in the bacterial and insect cell system and the products tested for their ability to bind F-actin, only a slight increase in association was found (Fig. 5c,d). Similarly, for the $\beta$ Sk TM expressed in SF9 cells, no increase in binding was evident when compared to the bacterially expressed Sk TM. This suggests that for those TMs that readily bind F-actin, this amino terminal acetylation has limited or no effect, but that for certain isoforms it may be critical.

\section{Presence of other tropomyosins can promote TM-1 association with actin filaments}

Tropomyosin binding to F-actin has been shown to involve cooperative interactions, due in part to head-to-tail overlap of coiled coil dimers. In addition we have demonsrated previously using $\alpha$ TM isoforms expressed in bacteria, that the nonmuscle isoform TM-5b could compete and displace the TMs 2, 3 or 5a from F-actin (Pittenger and Helfman, 1992). In order to test whether the presence of other TMs would affect the binding of TM-1, mixtures of expressed isoforms were incubated with Factin. As expected, TM-5b (expressed in bacteria) could displace TM-1 (data not shown). Surprisingly, we found that when increasing amounts of TM-1 (expressed in bacteria or insect cells) were incubated with F-actin for one hour and then equimolar amounts of TM- 2 were added for an additional hour, TM-1 binding was increased at low concentrations and inhibited at higher concentrations (see Fig. 6). When TM-2 was present, TM-1 binding appeared to saturate at $15 \mu \mathrm{M}(0.5$ $\mathrm{mg} / \mathrm{ml})$, lower than the $45 \mu \mathrm{M}(1.5 \mathrm{mg} / \mathrm{ml})$ concentration necessary in the absence of TM-2. However, the amount of TM- 1 bound at saturation was lower than in the absence of TM-2. This inhibition never precluded TM-1 binding, but amounts of TM-2 which saturate the actin filaments failed to 

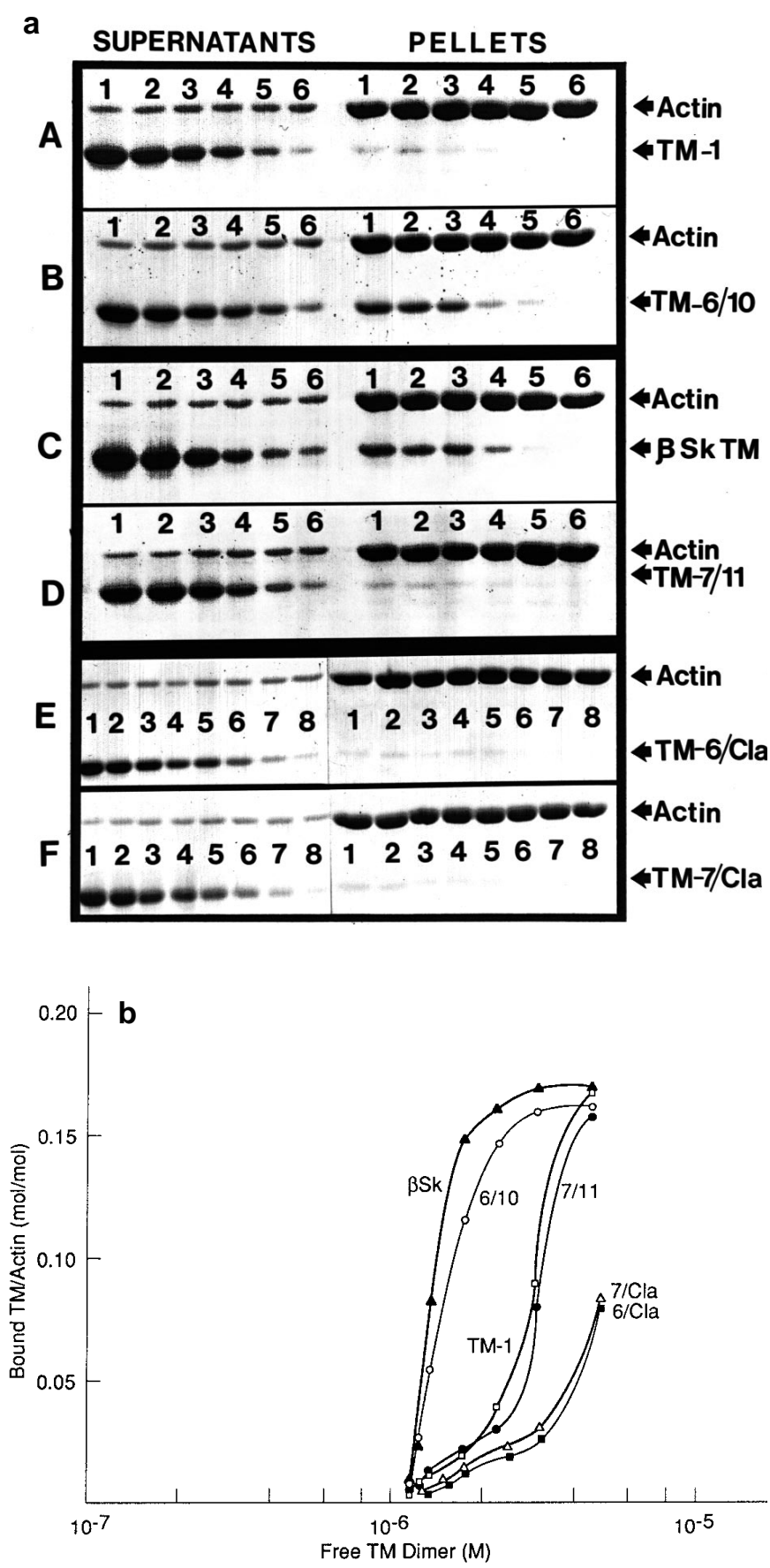

Fig. 3. Binding of the recombinant tropomyosins to filamentous actin. (a) The ability of the different tropomyosins to associate with F-actin was tested by a sedimentation assay. F-actin at a concentration of $1 \mathrm{mg} / \mathrm{ml}$ in a buffer of $100 \mathrm{mM} \mathrm{KCl}, 1 \mathrm{mM}$ DTT, $20 \mathrm{mM}$ sodium phosphate, $\mathrm{pH}$ 7.0, was incubated with decreasing amounts of each purified tropomyosin isoform produced in bacteria. The associated TM was then pelleted with the filamentous actin in an airfuge or tabletop ultracentrifuge. The supernatants and pellets were brought to the same final volume with SDS gel sample buffer and equal aliquots were resolved on a $12 \%$ SDS-polyacrylamide gel and visualized by Coomassie Brilliant Blue R. Tropomyosin concentrations are: lane $1,1 \mathrm{mg} / \mathrm{ml} \mathrm{TM}$; lane $2,0.75 \mathrm{mg} / \mathrm{ml}$; lane 3, $0.5 \mathrm{mg} / \mathrm{ml}$; lane 4, $0.25 \mathrm{mg} / \mathrm{ml}$; lane $5,0.125 \mathrm{mg} / \mathrm{ml}$; lane $6,0.06 \mathrm{mg}$ ml. (b) The data from (a) was quantified by densitometry and plotted as described in Results.

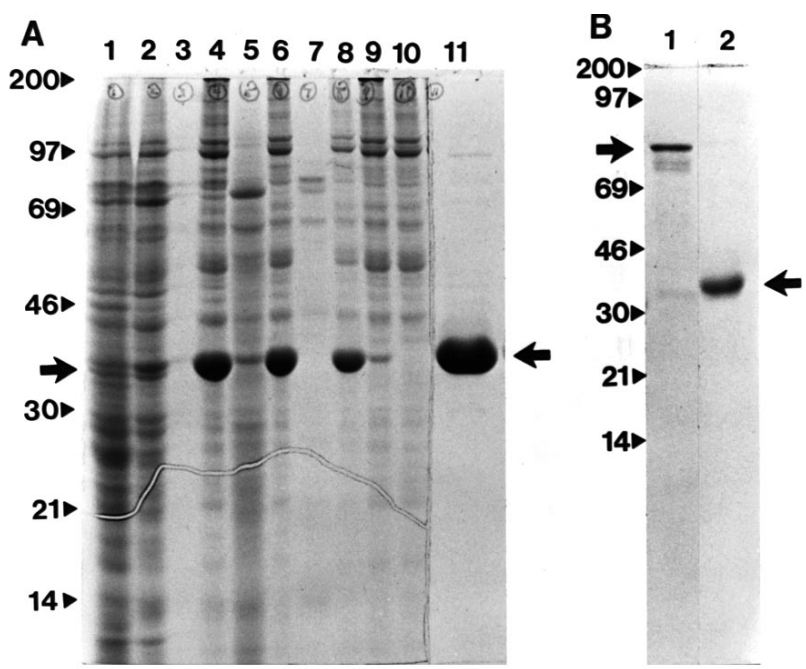

Fig. 4. (A) The purification of TMs expressed in insect cells. TM isoforms were purified following procedures similar to those used to prepare TMs expressed in bacteria. Lane 1, detergent lysed SF9 cells expressing TM-1. Lane 2, S100 supernatant fraction. Lane 3, S100 pellet. Lane 4, first $\mathrm{pH}$ precipitation pellet from S100 supernatant. Lane 5, supernatant from 4. Lane 6, pellet from second $\mathrm{pH}$ precipitation. Lane 7, supernatant from 6. Lane 8, resuspended TM at $\mathrm{pH} 7.5$ from third $\mathrm{pH}$ precipitation pellet prior to loading onto Mono Q column. Lane 9, pellet from centrifugation prior to loading Mono Q column ( $\mathrm{pH}$ 7.5). Lane 10, flow-through from Mono Q column. Lane 11, $10 \mu \mathrm{g}$ of TM-1 from pooled peak of protein from Mono $\mathrm{Q}$ column. (B) Purified bacterially expressed $83 \mathrm{kDa}$ caldesmon (lane 1) and purified TM-2 expressed in insect cells. Each isoform was purified as described and $3 \mu \mathrm{g}$ of each protein was electrophoresed through a $12 \%$ SDS-polyacrylamide gel. Minor bands in the caldesmon preparation are breakdown products. Arrows identify the positions of full length proteins.

displace the bound TM-1. And the presence of TM-1 did not alter the extent of TM-2 binding. This was also true when samples were incubated for longer periods (up to 4 hours) and the result does not appear to be kinetically limited. Thus it appears that TM-1 in the presence of TM-2 binds to a limited number of sites on actin filaments and that TM-2 facilitates such TM-1 binding in a cooperative manner. From quantifying the Coomassie Blue stained gels, the molar amounts of TM bound when each TM was at saturation appeared to be 1:6, TM-1 to TM-2. TM-1 binding was similarly increased when TM-3, another 284 amino acid $\alpha$ gene product, was present (data not shown). It should be noted that the amount of TM-2 bound appeared to be the same in the presence or absence of TM-1, but small changes of 5-10\% would be within experimental error and difficult to quantitate. However, this did not appear to be the case. Preliminary experiments involving more than two isoforms of TM became difficult to interpret without careful quantitation and are beyond the scope of the current work.

\section{Caldesmon enhances TM-1 binding to actin filaments}

Caldesmon is known to bind both actin and tropomyosin through residues in the carboxy third of the elongated molecule (Watson et al., 1990) although the exact binding sites and overlaps are not completely known. We tested whether $83 \mathrm{kDa}$ 
nonmuscle caldesmon would affect the F-actin binding of the different expressed TMs. The caldesmon was expressed in bacteria which produces an unphosphorylated $\mathrm{CaD}$, the form that readily binds F-actin (Yamashiro et al., 1990). TM-1 exhibited greatly enhanced binding even at subsaturating amounts of caldesmon (Fig. 7). By contrast the binding of the other TM isoforms was not dramatically affected by caldesmon (Fig. 7). The increase in binding of TM-1 lowered the half-saturating amount of TM-1 from $0.75 \mathrm{mg} / \mathrm{ml}$ to approximately 0.4 $\mathrm{mg} / \mathrm{ml}$ with an estimated decrease in $K_{\mathrm{a}}$ from $25 \mu \mathrm{M}$ to about 8-10 $\mu \mathrm{M}$. When caldesmon was first allowed to incubate with F-actin for one hour and TM-1 was subsequently added for an additional hour, the results were identical, suggesting that a TM-1:caldesmon complex is not first required for binding. When TM-1 and caldesmon were incubated in the absence of F-actin and subjected to centrifugation, no pellet was formed (data not shown). Acetylated TM-1 produced in the insect cell expression system also showed a large increase in binding in the presence of nonmuscle caldesmon (Fig. 7d), suggesting that the enhancement in binding is more than simply an alteration in the TM-1 amino terminus (see Discussion). The amount of pelleted F-actin did not change, nor did the extent of caldesmon binding when TM-1 was present. As shown in Fig. 8a, the

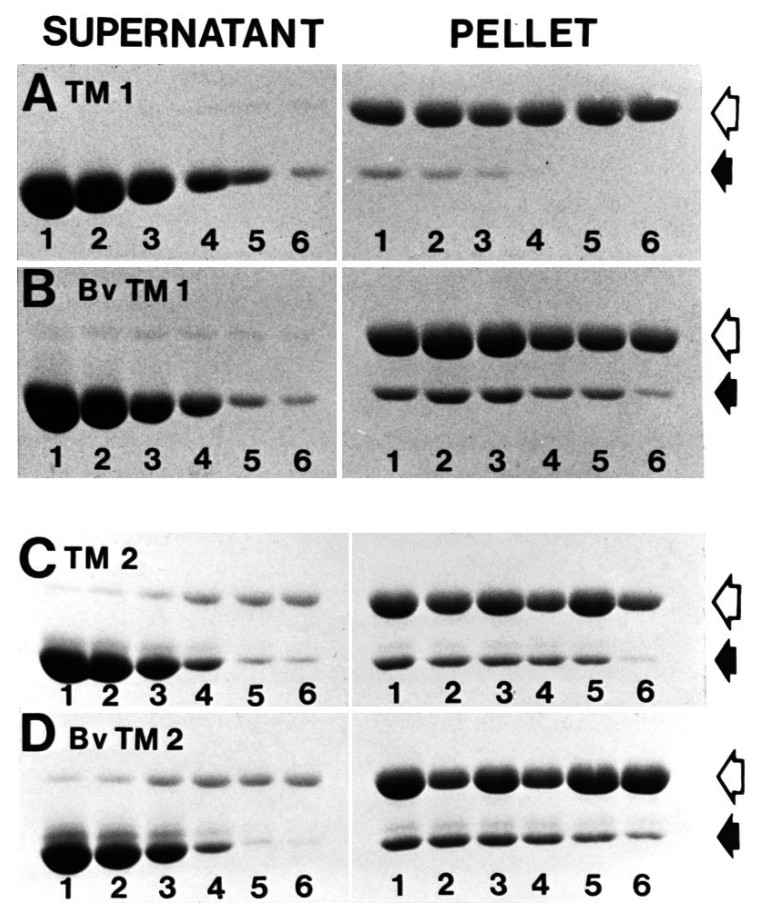

Fig. 5. Acetylated TM-1 produced in insect cells shows enhanced Factin association compared to unacetylated bacterially expressed TM-1. (A and B) Binding of bacterially expressed TM-1 is shown in $\mathrm{A}$ and the binding of the acetylated form expressed in baculovirus is shown in B. Solid arrow indicates the position of the Tm isoform on the gel, while the open arrow indicates the position of actin. F-actin at $1 \mathrm{mg} / \mathrm{ml}$ was incubated with decreasing amounts of TM $(1.0,0.75$, $0.5,0.25,0.125,0.06 \mathrm{mg} / \mathrm{ml}$ for lanes $1-6$, respectively) and the actin pelleted by centrifugation. There was enhanced binding of the acetylated form of TM-1 produced in insect cells relative to that expressed in bacteria. (C and D) Only a slight change in the affinity of TM-2 for actin was found when it was expressed in insect cells (D) as compared to that expressed in bacteria (C). chimeric TM-6/10 also showed an enhancement in binding in the presence of nonmuscle caldesmon, but not as dramatic as the TM-1. The expressed TM-7/11, TM-6Cla and TM-7Cla showed only a slight, if any enhancement in binding when caldesmon was present. Clearly the greatest enhancement of TM binding was seen with TM-1 which utilizes exons 6 and 11.

\section{Microinjection of fluorescently tagged TMs}

In order to try to identify any differences in the subcellular localization of the isoforms each of the bacterially produced $\beta$ TM isoforms was fluorescently labeled by reaction with lissamine rhodamine B sulfonyl chloride and the labeled TMs used in microinjection experiments. The proteins were microinjected into REF52 cells, a rat embryo fibroblast cell line with a well-spread morphology. These cells have been used previously for the microinjection of $\alpha$-TM isoforms (Pittenger and Helfman, 1992) and the expression of TMs in these cells has been well studied (Matsumura and YamashiroMatsumura, 1985; Matsumura et al., 1983).

The microinjection of $\beta \mathrm{Sk}$ TM and TM-6/10, isoforms which utilize exon 10, resulted in rapid and extensive incorporation into the microfilament system. As shown in Fig. 9, within 30 minutes after injection, labeling was seen throughout the cell, but was most intense near the site of injection. Labeling was also present at the cell periphery, where active reorganization of microfilaments is known to occur (Theriot and Mitchison, 1992). By 2 hours, the labeling was virtually uniform within the cell and characteristic tropomyosin stri-

\section{SUPERNATANTS}

PELLETS

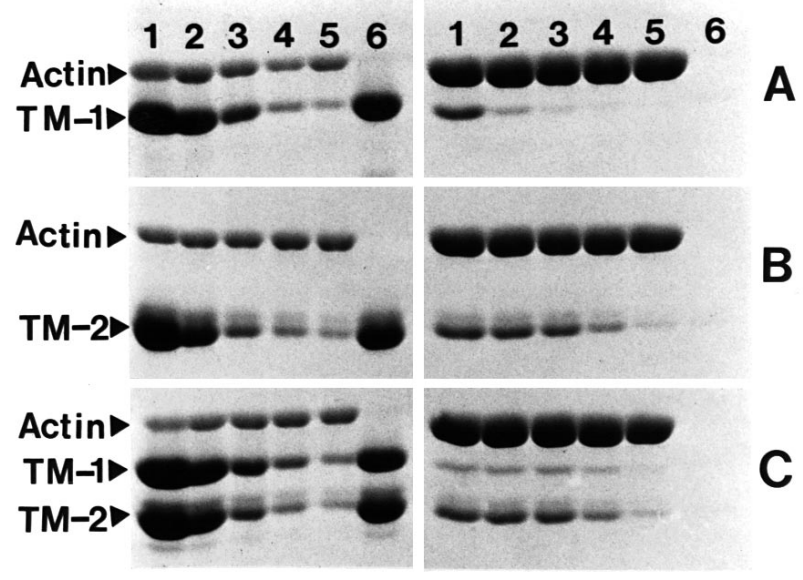

Fig. 6. F-actin binding assay reveals TM-2 enhances the binding of TM-1 to F-actin. The binding of TM-1 to F-actin was found to be enhanced when TM-2 was present. At low concentrations of TM-1, there was enhanced binding to F-actin when equimolar levels of TM2 were present. At saturating levels of TM-2, TM-1 could still bind to actin filaments, but to a lower saturating level than when TM-2 is absent. The presence of TM-1 did not appear to effect TM-2:actin association. (A) Bacterial TM-1 alone binding to F-actin.

(B) Bacterial TM-2 alone binding to F-actin. (C) Equal amounts of bacterially expressed TM-1 and TM-2 binding to F-actin. Lanes 1 to $5,1 \mathrm{mg} / \mathrm{ml}$ actin. Lane $1,1 \mathrm{mg} / \mathrm{ml}$ TM. Lane $2,0.5 \mathrm{mg} / \mathrm{ml}$ of each TM. Lane 3, $0.25 \mathrm{mg} / \mathrm{ml}$ of each TM. Lane $4,0.125 \mathrm{mg} / \mathrm{ml}$ of each TM. Lane 5, $0.06 \mathrm{mg} / \mathrm{ml}$ of each TM. Lane $6,1 \mathrm{mg} / \mathrm{ml}$ of each TM but no actin present. 


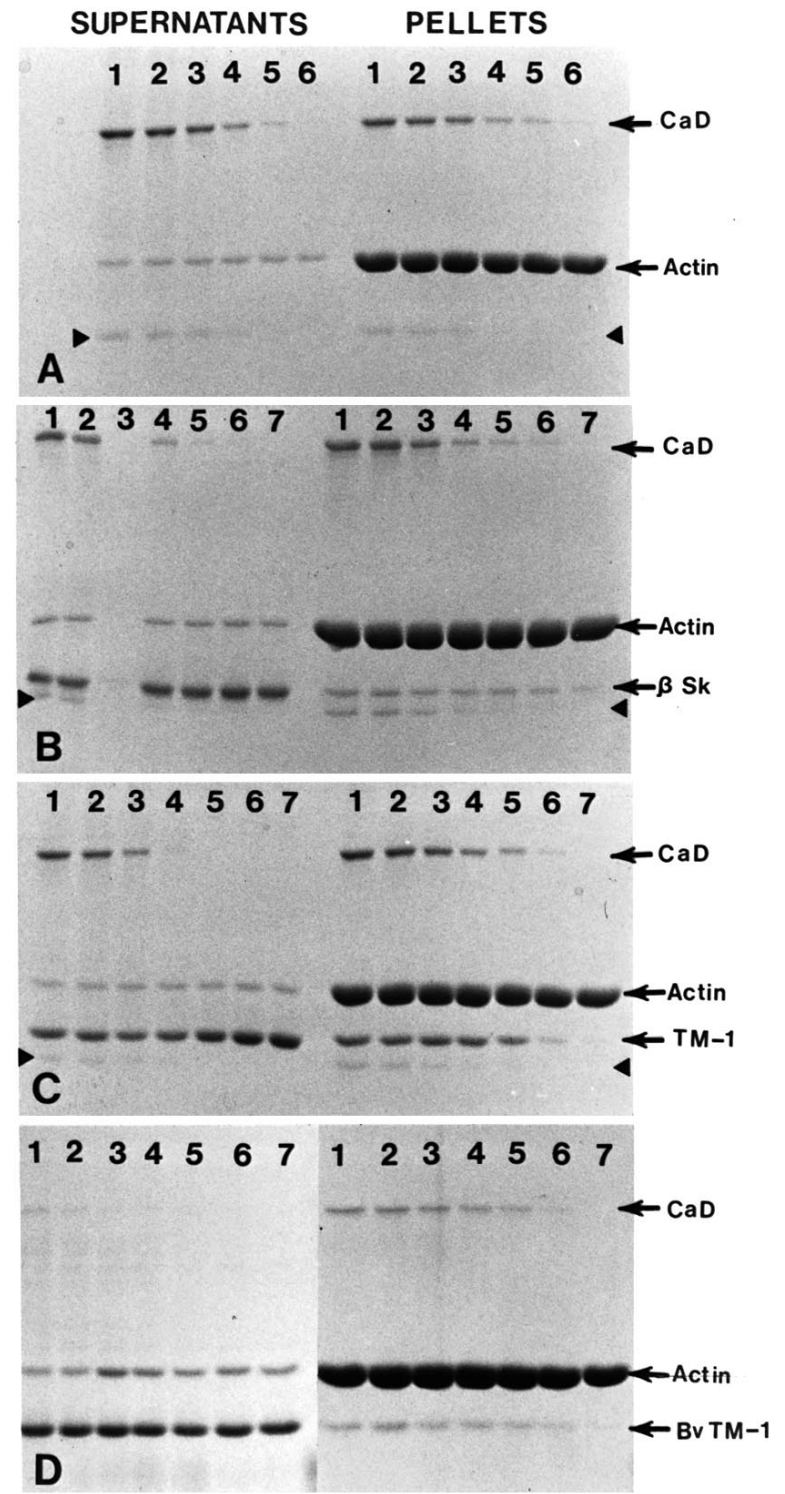

Fig. 7. Caldesmon ( $83 \mathrm{kDa}$ ) enhances the TM-1 association to Factin. Assays were performed to analyse the effect of nonmuscle caldesmon on the binding of TM isoforms to actin filaments. For this, the TM concentration of each isoform was that at the midpoint of the binding curve which would show the greatest change, when caldesmon has an effect. Decreasing amounts of the bacterially expressed nonmuscle caldesmon were added to the constant amount of TM isoform and $1 \mathrm{mg} / \mathrm{ml}$ of F-actin. A large change in the association of TM-1 with F-actin was noted as caldesmon was added up to $0.25 \mathrm{mg} / \mathrm{ml}$. (A) Caldesmon alone. Small arrowheads identify a caldesmon breakdown product that occurs during bacterial expression. (B) $0.125 \mathrm{mg} \mathrm{ml} \beta$ Sk TM. (C) $0.25 \mathrm{mg} / \mathrm{ml} \mathrm{TM}-1$. Caldesmon concentrations were: lane $1,1 \mathrm{mg} / \mathrm{ml}$; lane 2, 0.75 $\mathrm{mg} / \mathrm{ml}$; lane 3, $0.5 \mathrm{mg} / \mathrm{ml}$; lane 4, $0.25 \mathrm{mg} / \mathrm{ml}$; lane $5,0.125 \mathrm{mg} / \mathrm{ml}$; lane $6,0.06 \mathrm{mg} / \mathrm{ml}$.

ations were visible on stress fibers. Counterstaining actin filaments with fluorescein phalloidin revealed that at the light microscope level essentially all actin filaments had incorporated the microinjected TM. There appeared to be no deleterious effects on filament stability or cell viability, and labeled

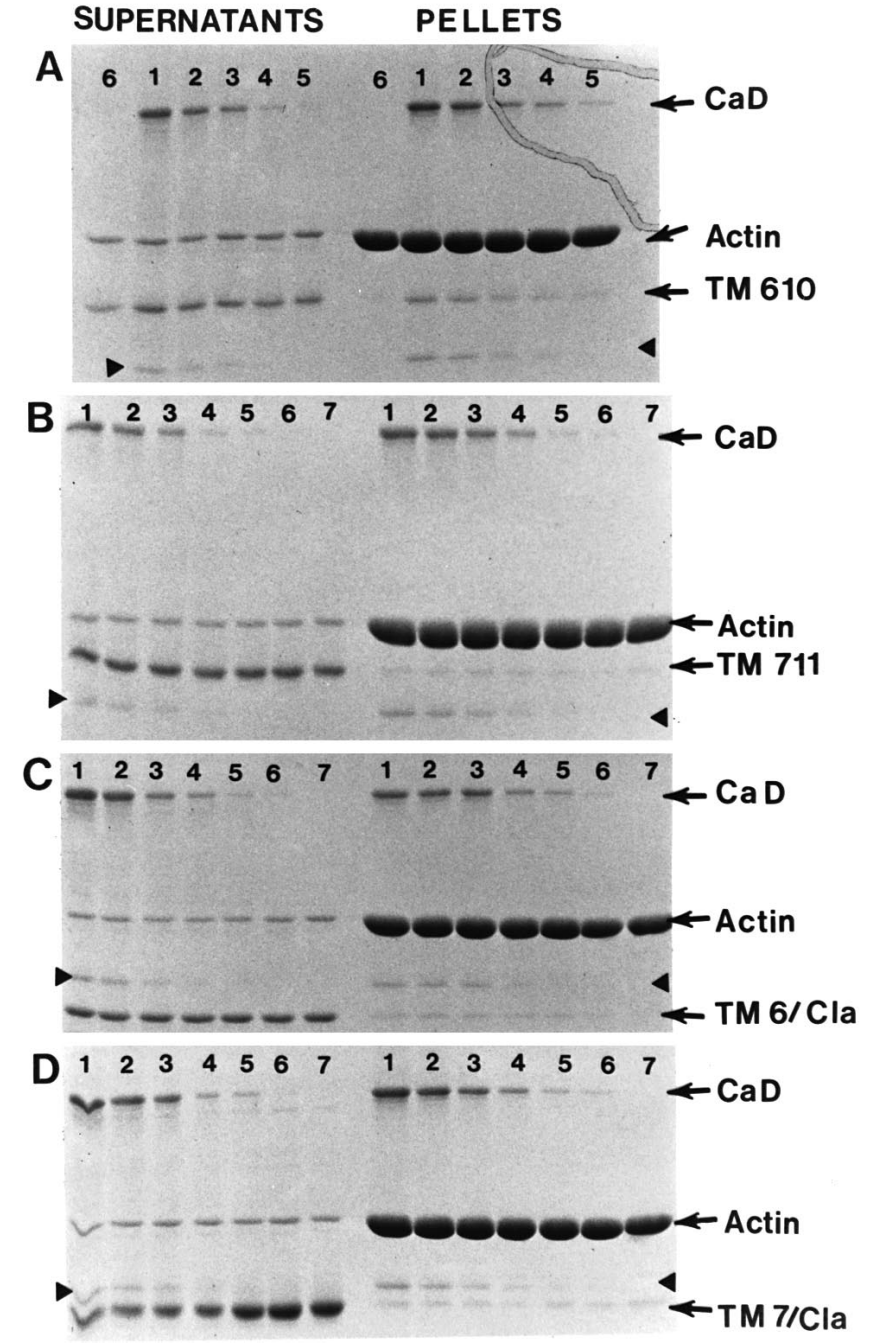

Fig. 8. Caldesmon has limited effect on the other $\beta$ TM isoforms. The effect of caldesmon on the binding of the chimeric $\beta$ TMs and the truncated forms to F-actin was tested. A limited effect was seen with TM 6/10 (A) but little or no effect was seen with TM-7/11 (B), TM-6Cla (C) or TM-7Cla (D). Concentration of TM 6/10 was 0.125 $\mathrm{mg} / \mathrm{ml}$; TM 7/11 was $0.25 \mathrm{mg} / \mathrm{ml}$; TM-6Cla was $0.25 \mathrm{mg} / \mathrm{ml}$; TM7Cla was $0.25 \mathrm{mg} / \mathrm{ml}$. As in Fig. 7, caldesmon concentrations were; lane $1,1 \mathrm{mg} / \mathrm{ml}$; lane 2, $0.75 \mathrm{mg} / \mathrm{ml}$; lane $3,0.5 \mathrm{mg} / \mathrm{ml}$; lane $4,0.25$ $\mathrm{mg} / \mathrm{ml}$; lane 5, $0.125 \mathrm{mg} / \mathrm{ml}$; lane $6,0.06 \mathrm{mg} / \mathrm{ml}$. Small arrowheads identify a caldesmon breakdown product.

filaments could be found in microinjected cells as late as 48 hours. Therefore, these two isoforms, although not normally found in these cells could readily compete with endogenous TMs and incorporate into microfilaments. They did not cause morphological changes in these well spread cells, nor did there appear to be any detrimental short term effects on cells.

When bacterially expressed TM- 1 and TM-7/11 were similarly labeled, microinjected and allowed to incorporate, only the faintest of filament staining was discernable (data not shown). This weak incorporation appeared to be consistent with the F-actin binding results and previous microinjection experiments (Pittenger and Helfman, 1992), suggesting that preparations of TMs that bound poorly to actin filaments in vitro were unable to label microfilaments following microin- 
jection. The presence of TM-2 and caldesmon within these cells apparently failed to enhance binding sufficiently. However, when TM-1 was produced in insect cells, fluorescently labeled and microinjected, extensive incorporation into microfilaments was seen (Fig. 10a). The labeling was not as intense as for $\beta$ Sk TM or TM-6/10 but this may reflect the limited incorporation of TM-1 in the presence of other isoforms as seen in the F-actin binding assay (Fig. 6c).

\section{DISCUSSION}

\section{Binding of $\beta$ TM gene products to F-actin}

The seven or eight tropomyosin isoforms found in fibroblasts are an integral part of the microfilament system and are thought to play a role in microfilament dynamics (Ishikawa et al., 1989a,b; Nishida et al., 1985). Tropomyosins are present as coiled coil dimers, which in fibroblasts have been shown to be homodimers (Lin et al., 1985; Matsumura and YamashiroMatsumura, 1985; M. Gimona, A. Watakabe and D. M. Helfman, unpublished) while in smooth and striated muscle, TMs form heterodimers of one $\alpha$ and one $\beta$ subunit. The intrinsic affinity of different TM homodimers towards F-actin has been shown to be quite different, whether the TMs are prepared from endogenous sources (Broschat and Burgess, 1986; Matsumura and Yamashiro-Matsumura, 1985) or from a heterologous expression system (Novy et al., 1993a,b; Pittenger and Helfman, 1992; Prasad et al., 1993). In order to investigate the association of $\beta$ tropomyosin gene products with F-actin and microfilaments, we have expressed the cDNAs for the different isoforms in bacteria and insect cells and tested the ability of the purified isoforms to bind to actin filaments in vitro and microfilaments in vivo. Purified TM-1 expressed from bacteria bound weakly to F-actin, while the acetylated version of this protein produced by expression in insect cells was found to bind F-actin much more readily, suggesting a structural requirement that this protein fulfills. Whether this increased binding results from a better fit to binding sites on actin or is due to a head to tail interactions of overlapping adjacent TMs or perhaps another factor remains to be determined. In addition, the $\beta$ Sk TM and the chimera TM$6 / 10$, which both use the same C-terminal exon were found to have a greater F-actin affinity than TM-1 or the chimera TM7/11. Exon 10 appears to provide for enhanced actin binding ability relative to exon 11 . Hence, the ends of the linear $\beta$ TM molecules have important structural information for actin association. Other investigators working with homodimers of bacterially expressed $\alpha$ Sk TM have shown that its binding to
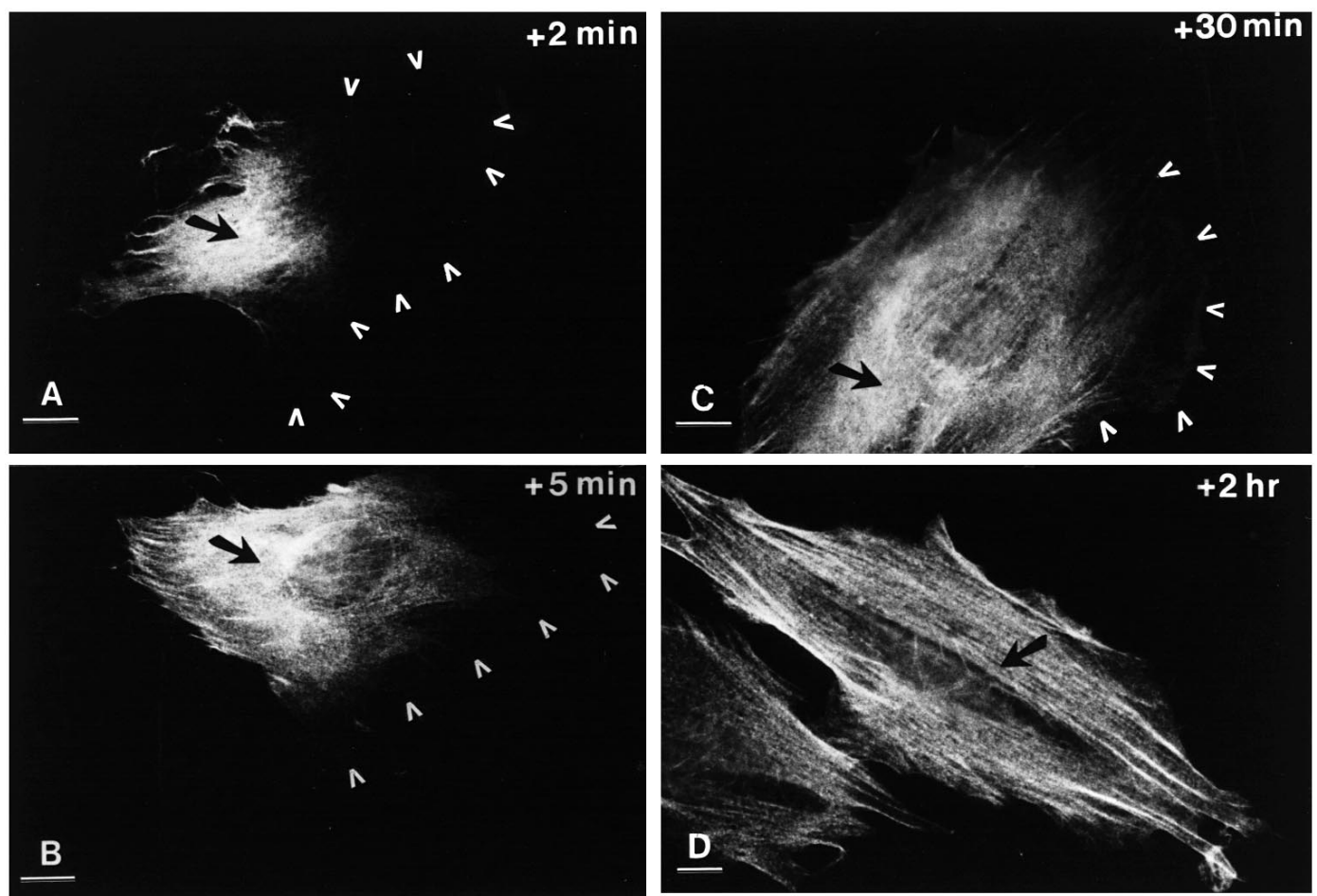

Fig. 9. Time course of incorporation of fluorescently tagged $\beta$ Sk TM microinjected into cultured rat fibroblasts. In order to discern whether microinjected TM isoforms would incorporate preferentially at particular regions of the cell or sites on microfilaments, fluorescently labelled TMs were microinjected into cultured rat fibroblasts (REF 52 cells). In this figure, $\beta$ Sk TM was fluorescently labeled with lissamine rhodamine $\mathrm{B}$ and the free dye removed by chromatography. The labeled TM was bound to F-actin and subjected to centrifugation to eliminate any denatured TM. The pelleted TM was then separated from actin (see Materials and Methods) and used for microinjection. At the appropriate times following injection, the coverslips were extracted for exactly 5 minutes with $0.2 \%$ Triton X-100 in a cytoskeletal stabilizing buffer to allow unincorporated TM to diffuse away and the cells were then fixed in $4 \%$ formaldehyde for 30 minutes. (A) Two minutes after microinjection. (B) Five minutes after microinjection. (C) At 30 minutes after microinjection. (D) At 2 hours after microinjection. Arrows indicate the site of injection. The incorporation of TM into microfilaments at early time points centered around the site of injection and appeared to occur along filaments. Uniform labeling of all microfilaments was found by 2 hours post injection, and coincided with all phalloidin labeled filaments (data not shown). 
F-actin requires a structural modification of the amino terminus that may be overcome by addition of as little as two amino acids (Montiero et al., 1994) or as many as eighty amino acids (Cho et al., 1990) to the amino terminal methionine of Sk $\alpha$ TM homodimers. It is interesting to note that the $\beta$ Sk TM does not seem to require $\mathrm{N}$-terminal acetylation while the $\alpha$ Sk TM does for the homodimers to have 'high' F-actin binding. There is a high degree of conservation between the amino acid sequences of these proteins. The first 18 amino acids are identical between the $\alpha$ and $\beta$ Sk TMs, there also being 3 conservative changes in the first 38 amino acids (see Lees-Miller and Helfman, 1991). The comparison of exons $2 b$ from the $\alpha$ and $\beta$ genes reveals 9 differences in 42 residues, 5 being nonconservative, usually a charged residue in $\beta$ Sk TM replacing a neutral or more hydrophobic residue found in $\alpha$ Sk TM. In the $\mathrm{C}$-terminal coding exons of the $\alpha$ and $\beta$ genes there are 5 encoded amino acid differences, most of which are conservative in nature. It will be of interest to determine if these are sufficient to explain the differences in F-actin binding between recombinant $\alpha$ and $\beta$ skeletal muscle isoforms.

\section{$\alpha$ TM gene products enhance association of TM-1 for F-actin}

In skeletal and smooth muscle, the TM exists as a coiled coil heterodimer of one $\alpha$ and one $\beta$ TM molecule. While virtually all cell types do express proteins from several TM genes, in fibroblasts the seven or eight isoforms of TMs are likely to function as homodimers (Lin et al., 1985; Matsumura and Yamashiro-Matsumura, 1985; M. Gimona, A. Watakabe and
D. M. Helfman, unpublished). These TM homodimers could bind to actin filaments and function cooperatively or competitively. For example, we have previously shown that, among the $\alpha$ gene products, 248 amino acid TM-5b could competitively displace the 284 amino acid TM-2 or TM-3 from actin filaments in vitro (Pittenger and Helfman, 1992). As shown in Fig. 6, the presence of TM-2 enhanced the affinity of TM-1 for F-actin but limited the extent of binding. In another series of experiments (data not shown) TM-3 had the same effect on the association of TM-1 for F-actin as TM-2 but TM-5b appeared only to compete with TM-1. When TM-1 and TM- 2 were both present, TM-5b continued to compete them both, about equally, from F-actin (data not shown).

If TMs stabilize microfilaments in vivo (Ishikawa et al., 1989a; Nishida et al., 1985), cells failing to express a full complement of TM isoforms may exhibit greater microfilament instability and may never establish stable actin networks or stress fibers. This seems to be the case for many transformed cells and suppression of the synthesis of certain TM isoforms is common following oncogenic transformation by chemical carcinogens, DNA or RNA viruses (Cooper et al., 1985; Hendricks and Weintraub, 1984; Lin et al., 1985; Matsumura et al., 1983). For example, a rat embryo fibroblast cell line transformed with the DNA transforming virus adenovirus type5 fail to express any detectable TM-1 (Matsumura et al., 1983). These cells have a pronounced spindle morphology and contain relatively few actin filaments compared to the parent cell line. Similarly NRK 1569 cells, derived from a well spread normal rat kidney cell line (NRK1570) that have been transformed by
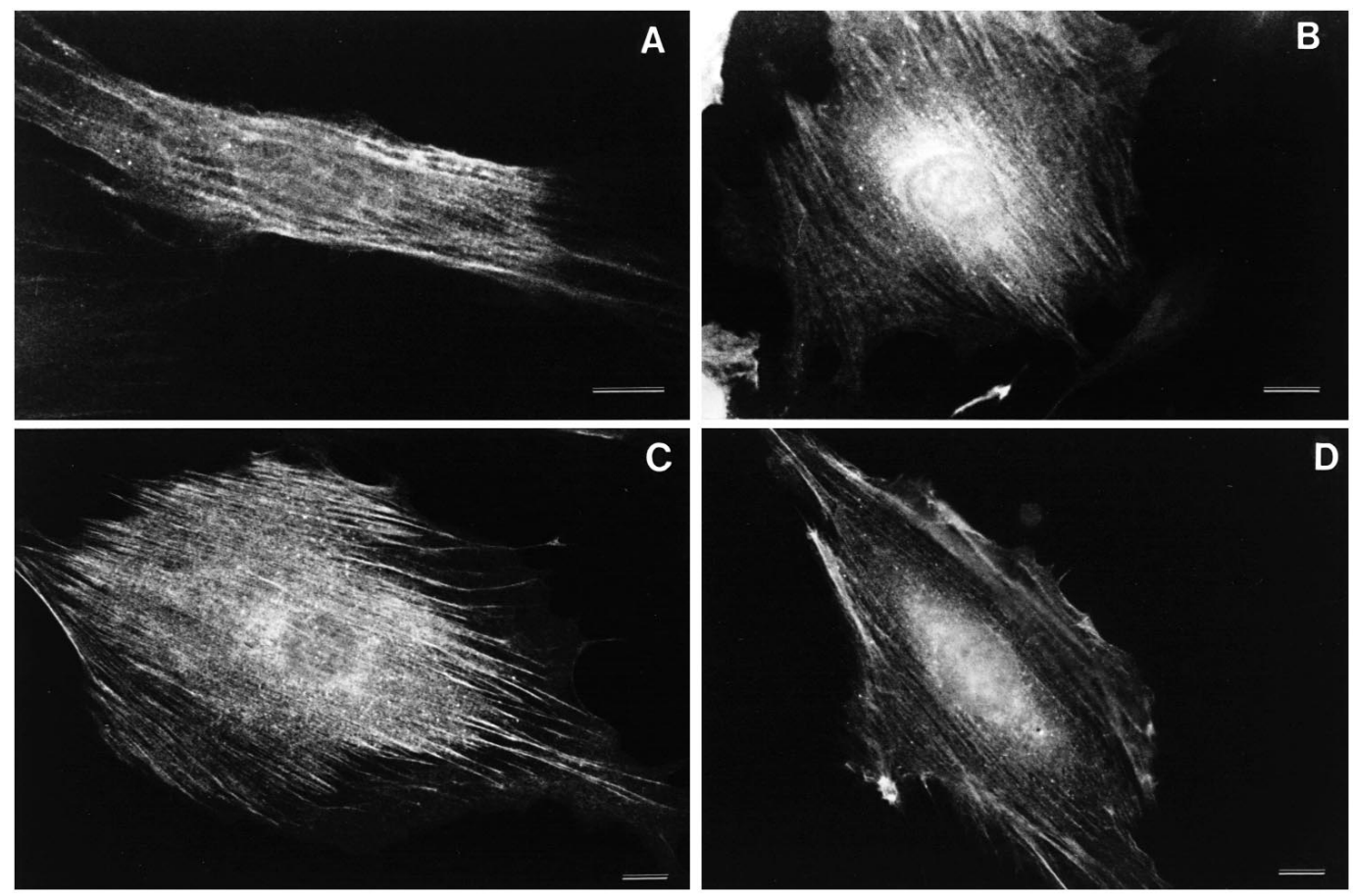

Fig. 10. $\beta$ gene TM isoforms show the same localization following microinjection. Expressed TM isoforms were fluorescently labeled with lissamine rhodamine B and purified as described in Fig. 9. (A) Acetylated TM-1 produced in insect cells. (B) TM-6/10 produced in bacteria. (C) $\beta$ Sk TM produced in bacteria. (D) Rabbit skeletal muscle TM, a mixture of $\alpha$ and $\beta$ isoforms. Although microfilament labeling appeared complete in 2 hours (see Fig. 9) for 6/10ch, $\beta$ Sk TM or TM from rabbit skeletal muscle, those isoforms which readily bound F-actin, best images for TM-1 were obtained 12-18 hours after microinjection. Hence, these photographs were all taken 12-14 hours after injection. TM-1 produced in bacteria as well as the two truncated isoforms TM-6Cla and TM-7Cla failed to incorporate into the microfilaments of injected cells to levels which allowed visualization. 
the v-ras containing Kirsten RNA virus grow as quite rounded cells, loosely attached to the substrate. These cells do not produce detectable TM-2 or TM-3 proteins (Matsumura et al., 1983). Recently, it has been reported that the $3^{\prime}$ untranslated region of $\alpha$ tropomyosin mRNA may suppress transformation by an as yet unidentified mechanism (Rastinejad et al., 1993).

\section{Caldesmon promotes TM-1 binding to F-actin}

Nonmuscle $83 \mathrm{kDa}$ caldesmon $(\mathrm{CaD})$ is known to have a periodic localization along microfilaments (YamashiroMatsumura and Matsumura, 1988) and binds tropomyosin through residues in its C-terminal half (Watson et al., 1990). Lin and co-workers have recently shown that forced expression of the carboxy-terminal half of nonmuscle $\mathrm{CaD}$ can stabilize TM association and enhance microfilament stability in $\mathrm{CHO}$ cells (Warren et al., 1994). To investigate the effect of caldesmon on the association of $\beta \mathrm{TM}$ isoforms with actin filaments, the full length bacterially expressed $83 \mathrm{kDa} \mathrm{CaD}$ protein was included in the TM:F-actin association assays. As we have shown in Fig. 7, caldesmon has a strong positive effect on the binding of TM-1 to F-actin. This isoform utilizes the alternatively spliced exons 6 (internal) and 11 (carboxyterminal). The binding of the isoform $\beta$ Sk TM and chimera TM-6/10 was affected in a minimal but positive manner when
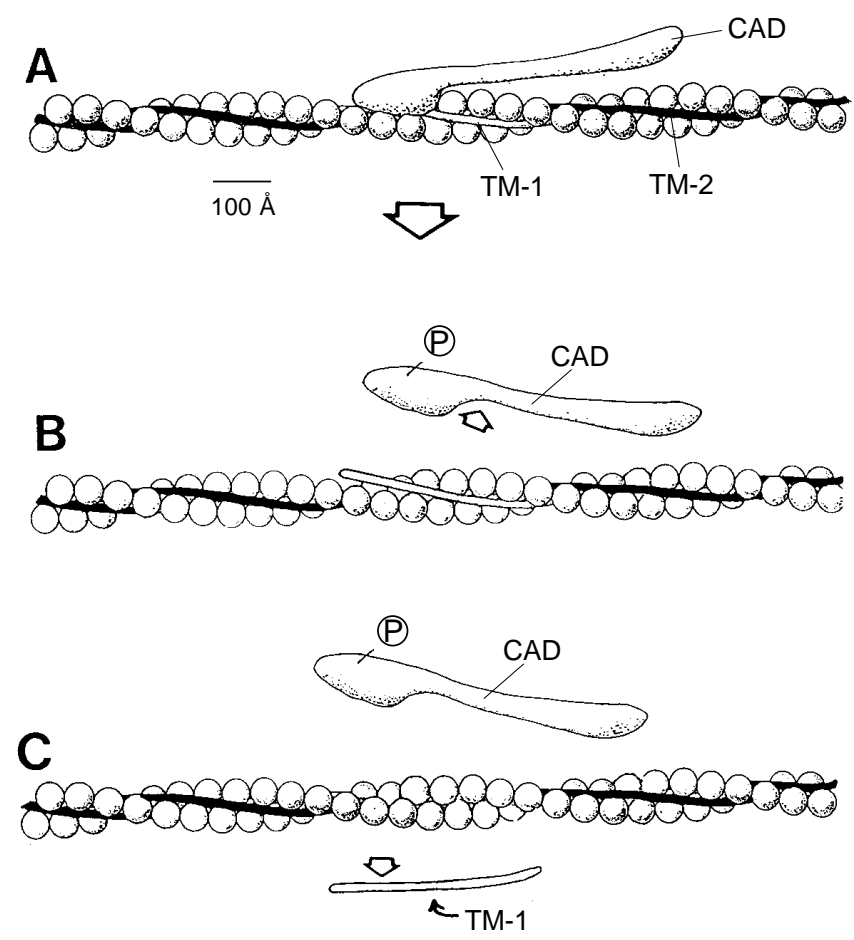

Fig. 11. Diagram of the association of TM-1, TM-2, and caldesmon (CAD) with F-actin. (A) A diagram of the association of TM-1, TM2 and caldesmon that is consistent with the results is shown; TM-1 is indicated in white and TM-2 in black. TM-2 binds along most of the F-actin filament, but positions are also occupied by TM-1, which is stabilized by the overlaps with TM-2 and the presence of nonmuscle caldesmon (nonphosphorylated). (B) Events which require filament reorganization may proceed by first removing caldesmon (in this case by phosphorylation). TM-1 association is weakened and slowly becomes detached. (C) The actin filament is then naked and susceptible to severing activities, where TM-1 was previously bound. Bar, $100 \AA$. caldesmon was present, while little or no effect was seen with the expressed chimera TM-7/11. The expressed, truncated proteins TM-6Cla and TM-7Cla showed virtually no increase in actin binding when caldesmon was present. Hence, among these TM proteins, there is a requirement for the exons 6 and 11 to achieve the maximal enhancement of TM binding by 83 kDa caldesmon.

The enhancement of TM-1 binding to F-actin in the presence of $83 \mathrm{kDa} \mathrm{CaD}$ agrees well with the reports of $140 \mathrm{kDa}$ smooth muscle caldesmon enhancing the binding of smooth muscle TM or recombinant $\beta$ smooth muscle TM (identical to TM-1) to actin filaments (Novy et al., 1993a). The $83 \mathrm{kDa}$ caldesmon has not been as extensively studied as the smooth muscle counterpart, however, similar properties include the binding of TM and calmodulin, as well as filamentous actin and the inhibition of actomyosin ATPase. The interaction of $83 \mathrm{kDa}$ caldesmon with $\mathrm{F}$-actin has been shown to be regulated by $\mathrm{Ca}^{2+} /$ calmodulin or phosphorylation by the mitotically active cdc2 kinase (Yamashiro et al., 1990). The association of $83 \mathrm{kDa}$ caldesmon with the cytoskeleton is known to be inhibited by elevated $\mathrm{Ca}^{2+} /$ calmodulin levels, and increases in levels of intracellular $\mathrm{Ca}^{2+}$ would be expected to allow activation of actomyosin ATPase activity and increases in cellular motile activities. Similarly, the release of $\mathrm{CaD}$ (see Fig. 11) followed by a weakening of the TM-1:microfilament association, may allow severing proteins such as gelsolin, to cleave the unprotected actin filaments efficiently. As an example, in a motile fibroblast that is undergoing changes in morphology, local microfilament reorganization involving TMs and $\mathrm{CaD}$ could be responsive to $\mathrm{Ca}^{2+}$ levels prompted from intracellular stores or membrane fluxes by receptor-based mechanisms. The sensitivity of $\mathrm{CaD}$ to cdc2 kinase phosphorylation may promote the pronounced alterations of the cytoskeleton that must occur prior to mitosis. As the cell then progresses through the cell cycle, the dramatic changes that occur throughout the cytoskeleton in readiness for mitosis could be controlled by phosphorylation events on $\mathrm{CaD}$ and other components of the cytoskeleton.

\section{Fluorescently taggged isoforms microinjected into cells do not show differential subcellular localization}

The incorporation of microinjected $\beta$ Sk TM and TM-6/10 produced in bacteria was rapid and extensive throughout the fibroblast cytoskeleton as was the TM purified from rabbit muscle (Figs 9 and 10). The bacterially produced TM-1 failed to incorporate, but the acetylated TM-1 from the insect cell expression system was found in the characteristic striations along stress fibers. When the TM localization was compared with fluorescein-phalloidin staining, all actin filaments appeared to have the introduced TMs bound along their length. No difference could be discerned between the localization of these microinjected TMs. It would be intriguing to know whether the periodic $\mathrm{CaD}$ localization previously reported (Bretscher and Lynch, 1985; Yamashiro et al., 1990) correlates with the periodic staining of TM-1.

While microinjection of labeled TM protein into fibroblasts has not yet shown a difference in isoform localization, antibodies that can distinguish between certain isoforms have been used to show such differences in 293 cells (Lin et al., 1988) or the more highly differentiated porcine intestinal epithelial 
cells, LL-CPK 1 (C. Temm, D. M. Helfman, and B. Jockusch, unpublished). Furthermore, tropomyosin isoform expression has been shown to respond to altered actin isoform expression (Schevzov et al., 1993) and actin isoforms have been shown to sort in microvascular pericytes (DeNofrio et al., 1989). By microinjecting protein isoforms, it is possible that a mechanism for isoform sorting that occurs at the level of mRNA has been circumvented. This is a testable hypothesis and future experiments will address some of these questions.

The expression of the alternatively spliced TMs is found to vary in a tissue specific manner that is conserved across species, suggesting differences in their functions. There are regions of TM that are encoded by conserved exons and those that are encoded by alternatively spliced exons. The complexity of TM expression is unlikely to be the result of redundancy as a wealth of in vitro experiments has shown TM isoforms to vary in their properties towards actin and actin binding or severing proteins. Future work should allow a better appreciation of the cellular functions that tropomyosin isoforms facilitates and how their interactions with other proteins of the microfilament system effect its dynamics.

The plasmid to produce recombinant caldesmon was kindly provided by F. Matsumura and S. Yamashiro. Special thanks to Phil Renna and Jim Duffy for art work. DMH is support by a grant from the National Cancer Institute (CA58607) and is an Established Investigator of the American Heart Association.

\section{REFFERENCES}

Bartegi, A., Ferraz, C., Fattoum, A., Sri Widada, J., Heitz, F., Kassab, R. and Liautard, J.-P. (1990). Construction, expression and unexpected regulatory properties of a tropomyosin mutant with a 31-residue deletion at the C-terminus (exon 9). Eur. J. Biochem. 194, 845-852.

Bretscher, A. and Lynch, W. (1985). Identification and localization of immunoreactive forms of caldesmon in smooth and nonmuscle cells: a comparison with the distribution of tropomyosins and alpha-actinin. J. Cell Biol. 100, 1656-1663.

Broschat, K. O. and Burgess, D. R. (1986). Low Mr tropomyosin isoforms from chicken brain and intestinal epithelium have distinct actin-binding properties. J. Biol. Chem. 261, 13350-13359.

Cho, Y.-J., Liu, J. and Hitchcock-DeGregori, S. E. (1990). The amino terminus of muscle tropomyosin is a major determinant for function. J. Biol. Chem. 265, 538-545.

Cooper, H. L., Feuerstein, N., Noda, M. and Bassin, R. H. (1985). Suppression of tropomyosin synthesis, a common biochemical feature of oncogenesis by structurally diverse retroviral oncogenes. Mol. Cell. Biol. 5, 972-983.

DeNofrio, D., Hoock, T. C. and Herman, I. M. (1989). Functional sorting of actin isoforms on microvascular pericytes. J. Cell Biol. 109, 191-202.

Diacumakos, E. G. (1973). Methods for micromanipulation of human somatic cells in culture. Meth. Cell Biol. 7, 287-302.

Ebashi, S. E., Endo, M. and Ohtsuki, I. (1969). Control of muscle contraction. Quart. Rev. Biophys. 2, 351-384.

Goodwin, L. O., Lees-Miller, J. P., Leonard, M. A., Cheley, S. B. and Helfman, D. M. (1991). Four fibroblast tropomyosin isoforms are expressed from the rat $\alpha$ tropomyosin gene through the use of alternative promoters and alternative RNA processing. Mol. Cell. Biol. 10, 1729-1742.

Graessmann, A., Graessman, M. and Mueller, C. (1979). Micorinjection of SV40 nucleic acids and SV40 T-antigen. Meth. Enzymol.

Greene, L. E. and Eisenberg, E. (1980). Cooperative binding of myosin subfragment-1 to the actin-troponin-tropomyosin complex. Proc. Nat. Acad. Sci. USA 77, 2161-2620.

Heald, R. W. and Hitchcock-DeGregori, S. E. (1988). The structure of the amino terminus of tropomyosin is critical for binding to actin in the presence and absence of troponin. J. Biol. Chem. 263, 5254-5259.

Helfman, D. M., Cheley, S., Kuismanen, E., Finn, L. A. and YamawakiKataoka, Y. (1986). Nonmuscle and muscle tropomyosin isoforms are expressed from a single gene by alternative RNA splicing and polyadenylation. Mol. Cell. Biol. 6, 3582-3595.

Hendricks, M. and Weintraub, H. (1984). Multiple tropomyosin polypeptides in chicken embryo fibroblasts: differential repression of transcription by Rous sarcoma virus transformation. Mol. Cell. Biol. 4, 18231833.

Ishikawa, R., Yamashiro, S. and Matsumura, F. (1989a). Differential modulation of actin-severing activity of gelsolin by multiple isoforms of cultured rat cell tropomyosin. J. Biol. Chem. 264, 7490-7497.

Ishikawa, R., Yamashiro, S. and Matsumura, F. (1989b). Annealing of gelsolin-severed actin filaments by tropomyosin in the presence of calcium. Potentiation of the annealing process by caldesmon. J. Biol. Chem. 264, 16746-16770.

Laemmli, U. K. (1970). Cleavage of structural proteins during the assembly of the head of bacteriophage T4. Nature 227, 680-685.

Lees-Miller, J. P., Goodwin, L. O. and Helfman, D. M. (1990). Three novel brain tropomyosin isoforms are expressed from the rat $\alpha$-tropomyosin gene through the use of alternative promoters and alternative RNA processing. Mol. Cell. Biol. 10, 1729-1742.

Lees-Miller, J. P. and Helfman, D. M. (1991). The molecular basis for tropomyosin isoform diversity. BioEssays 13, 429-437.

Lin, J. J.-C., Helfman, D. M., Hughes, S. H. and Chou, C.-S. (1985). Tropomyosin isoforms in chicken embryo fibroblasts: Purification, characterization, and changes in Rous sarcoma virus transformed cells. $J$. Cell Biol. 100, 692-703.

Lin, J. J.-C., Hegmann, T. E. and Lin, J. L.-C. (1988). Differential localization of tropomyosin isoforms in cultured nonmuscle cells. J. Cell Biol. 107, 563-572.

MacLeod, A. R. and Gooding, C. (1988). Human hTM $\alpha$ gene: expression in muscle and nonmuscle tissue. Mol. Cell. Biol. 8, 433-440.

Marston, S. B. and Smith, C. W. J. (1985). The thin filaments of smooth muscles. J. Muscle Res. Cell Motil. 6, 669-708.

Matsudaira, P. (1987). Sequence from picomole quantities of proteins electroblotted onto polyvinylidene difluoride membranes. J. Biol. Chem. 262, 10035-10038.

Matsumura, F., Lin, J. J.-C., Yamashiro-Matsumura, S., Thomas, G. P. and Topp, W.C. (1983). Differential expression of tropomyosin forms in the microfilaments isolated from normal and transformed rat cultured cells. $J$. Biol. Chem. 258, 13954-13964.

Matsumura, F. and Yamashiro-Matsumura, S. (1985). Purification and characterization of multiple isoforms of tropomyosin from rat cultured cells. J. Biol. Chem. 260, 13851-13859.

Montiero, P. B., Latero, R. C., Ferro, J. A. and Reinach, F. C. (1994). Functional $\alpha$ tropomyosin produced in E. coli. A dipeptide extension can substitute for the amino terminal acetyl group. J. Biol. Chem. 269, 1046110466.

Nishida, E., Muneyuki, E., Maekawa, S., Ohta, Y. and Sakai, H. (1985). An actin-depolymerizing protein (destrin) from porcine kidney. Its action on Factin containing or lacking tropomyosin. Biochemistry 24, 6624-6630.

Novy, R. E., Liu, L.-F., Lin, C. S., Helfman, D. M. and Lin, J. J.-C. (1993a). Expression of smooth muscle and nonmuscle tropomyosins in E. coli and characterization of bacterially produced tropomyosins. Biochim. Biophys. Acta 1162, 255-265.

Novy, R. E., Sellers, J. R., Liu, L.-F. and Lin, J. J.-C. (1993b). In vitro functional characterization of bacterially expressed human fibroblast tropomyosin isoforms and their chimeric mutants. Cell Motil. Cytoskel. 26, 248-261.

Pittenger, M. F. and Helfman, D. M. (1992). In vitro and in vivo characterization of four fibroblast tropomyosins produced in bacteria: TM-2, TM-3, TM-5a and TM-5b are colocalized in interphase fibroblasts. J. Cell Biol. 118, 841-858.

Pittenger, M. F., Kazzaz, J. A. and Helfman, D. M. (1994). Functional properties of nonmuscle tropomyosin isoforms. Curr. Opin. Cell Biol. 6, 96104.

Prasad, G. L., Fuldner, R. A. and Cooper, H. L. (1993). Expression of transduced tropomyosin 1 cDNA suppresses neoplastic growth of cells transformed by the ras oncogene. Proc. Nat. Acad. Sci. USA 90, 7039-7043.

Ranucci, D., Yamakita, Y., Matsumura, F. and Hitchcock-DeGregori, S. (1993). Incorporation of microinjected mutant and wildtype recombinant tropomyosins into stress fibers of fibroblasts. Cell Motil. Cytoskel. 24, 119128.

Rastinejad, F., Conboy, M. J., Rando T. A. and Blau, H. M. (1993). Tumor suppression by RNA from the $3^{\prime}$ untranslated region of $\alpha$-tropomyosin. Cell 75, 1107-1117. 
Sambrook J., Fritsch, E. F. and Maniatis, T. (1989). Molecular Cloning: a Laboratory Manual. Cold Spring Harbor Laboratory Press, Cold Spring Harbor, NY.

Sanger, F., Nicklen, S. and Coulson, A. R. (1977). DNA sequencing with chain termination inhibitors. Proc. Nat. Acad. Sci. USA 74, 5463-5467.

Schevzov, G., Lloyd, C., Hailstone, D. and Gunning, P. (1993). Differential regulation of tropomyosin isoform organization and gene expression in response to altered actin gene expression. J. Cell Biol. 121, 811-821.

Stamm, S., Casper, D., Lees-Miller, J. P. and Helfman, D. M. (1993). Brainspecific tropomyosins $\mathrm{TMBr}-1$ and $\mathrm{TMBr}-3$ have distinct patterns of expression during development and in adult brain. Proc. Nat. Acad. Sci. USA 90, 9857-9861.

Studier, F. W., Rosenberg, A. H., Dunn, J. J. and Dubendorff, J. W. (1990). Use of T7 RNA polymerase to direct expression of cloned genes. Meth. Enzymol. 185, 60-89.

Theriot, J. A. and Mitchison, T. J. (1992). Comparison of actin and cell surface dynamics in motile fibroblasts. J. Cell Biol. 118, 367-377.

Urbancikova, M. and Hitchcock-DeGregori, S. E. (1994). Requirement of the amino terminal modification for striated muscle $\alpha$-tropomyosin function. J. Biol. Chem. 269,

Wang, Y.-C. and Rubenstein, P. A. (1992). Splicing of two alternative exon pairs in $\beta$-tropomyosin pre-mRNA is independently controlled during myogenesis. J. Biol. Chem. 267, 12004-12010.

Warren, K. S., Lin, J. L.-C., Wambolt, D. D. and Lin, J. J.-C. (1994). Overexpression of human fibroblast caldesmon fragment containing actin, calcium/calmodulin, and tropomyosin-binding domains stabilizes endogenous tropomyosin and microfilaments. J. Cell Biol. 125, 359-368.

Watson, M. H., Kuhn, A. E., Novy, R. E., Lin, J. J.-C. and Mak, A. S. (1990). Caldesmon-binding sites on tropomyosin. J. Biol. Chem. 265, 1886018865 .

Weinberger, R. P., Henke, R. C., Tolhurst, O., Jeffrey, P. L. and Gunning, P. (1993). Induction of neuron-specific tropomyosin mRNAs by nerve growth factor is dependent on morphological differentiation. J. Cell Biol. 120, 205-215.

Yamashiro, S., Yamakita, Y., Ishikawa, R. and Matsumura, F. (1990). Mitosis specific phosphorylation causes $83 \mathrm{~K}$ nonmuscle caldesmon to dissociate from microfilaments. Nature 344, 675-678.

Yamashiro-Matsumura, S. and Matsumura, F. (1988). Characterization of $83 \mathrm{kd}$ nonmuscle caldesmon from cultured rat cells: stimulation of actin binding of nonmuscle tropomyosin and periodic localization along microfilaments like tropomyosin. J. Cell Biol. 106, 1973-1978.

Yamashiro-Matsumura, S., Ishikawa, R. and Matsumura, F. (1988), Purification and characterization of $83 \mathrm{kDa}$ nonmuscle caldesmon from cultured rat cells: changes in its expression upon L6 myogenesis. Protoplasma (Suppl.) 2, 9-21

Yamawaki-Kataoka, Y. and Helfman, D. M. (1985). Rat embryo fibroblast tropomyosin 1. J. Biol. Chem. 260, 14440-14445.

(Received 9 January 1995 - Accepted 22 June 1995) 